\title{
Genotoxicity Tests and Their Contributions in Aquatic Environmental Research
}

\author{
Alaa G. M. Osman ${ }^{1,2}$ \\ ${ }^{1}$ Department of Zoology, Faculty of Science, Al-Azhar University (Assiut Branch), Assiut, Egypt \\ ${ }^{2}$ Department of Ecophysiology and Aquaculture, Leibniz-Institute of Freshwater Ecology and Inland Fisheries, \\ Berlin, Germany \\ Email: osman@igb-berlin.de
}

Received 10 September 2014; revised 6 October 2014; accepted 1 November 2014

Copyright (C) 2014 by author and Scientific Research Publishing Inc.

This work is licensed under the Creative Commons Attribution International License (CC BY). http://creativecommons.org/licenses/by/4.0/

(c) (i) Open Access

\section{Abstract}

As many chemicals with genotoxic potential are emitted to surface water, genotoxicity tests are gaining importance which led to the development of several techniques to detect directly DNA damage. The relevance of detecting the genotoxic risks associated with water pollution was firstly perceived in the late 1970s. Since that time several tests have been developed for evaluating DNA alterations in aquatic animals. These tests rely on the premise that any changes to DNA may have long-lasting and profound consequences. Sister chromatid test, chromosome aberrations, comet assay, and micronucleus test are currently the most widely employed methods to detect DNA lesions in ecotoxicology. Chromosomal aberration and sister chromatid exchanges are time consuming, resource intensive and require proliferating cell population. Hence, Comet assay and Micronucleus test as cost effective and more sensitive test systems have now been introduced for assessing the genotoxicity of chemicals. This review presents a synthesis of the state of the art in the methodologies of comet assay and micronucleus test and their contributions in aquatic environmental research. The text explores the latest knowledge and thinking on these very important approaches for the assessment of environmental health, management, and conservation. The primary concern of the present review is the measurement of genotoxic potential in aquatic organisms under field and laboratory conditions, where effects of chemicals at different levels of biological organization can be examined.

\section{Keywords}

Aquatic Environmental Research, Genotoxicity Tests, Aquatic Organisms, Comet Assay, Micronucleus Test 


\section{Introduction}

One of the problems affecting the health of aquatic organisms is the exposure of their aquatic environment to several hazards, which may be chemical, physical or biological contaminants. These hazards may induce genetic alterations and carcinogenesis in aquatic organisms [1]. Because of the continued production and release of these hazards into the aquatic environment, the investigation of the genotoxic potential of aquatic environment has become a major task in the monitoring of environmental pollution [2]. The analysis of environmental genotoxicity provides early warning signals of adverse long-term effects of the contamination [3]. Genotoxicity refer mainly to responses measured in nucleic acids. These include the measurement of alterations in either DNA or mRNA. Effects may manifest as either damage to the genome or some adaptive change in gene expression [4]. The assessment of genotoxic potential in aquatic environment is one of the main tasks of environmental monitoring to control pollution.

The biomonitoring of genotoxicity in aquatic organisms is important for several reasons. First, from the ecological perspective, the protection of genetic diversity in natural populations is important for population survival, and avoiding contaminant-induced mutations that skew genetic diversity is desirable [5]-[7]. Second, the detection of carcinogenic effects in aquatic organisms is needed to assess the health of aquatic organisms, as well as to prevent carcinogens from entering the food chain to humans [8]. Exposure to toxic substance can damage the DNA of living cells. If these DNA lesions are not repaired they can initiate a cascade of biological consequences at the cellular, morphological, whole animal and finally at the community and population level [9]. As many chemicals with genotoxic potential are emitted to surface water, genotoxicity tests are gaining importance which led to the development of several techniques to detect directly DNA damage and to identify such pollutants. The relevance of detecting the genotoxic risks associated with water pollution was firstly perceived in the late 1970 s. Since that time several tests have been developed for evaluating DNA alterations in aquatic animals. The possibility of using changes in DNA integrity to the genetic material as markers of exposure and effect of genotoxicants has previously been investigated [10]. The presence of DNA adducts has been taken as evidence of exposure to specific genotoxicants [11]. These tests rely on the premise that any changes to DNA may have longlasting and profound consequences [4]. Sister chromatid test, chromosome aberrations, comet assay, and micronucleus test are currently the most widely employed methods to detect DNA lesions in ecotoxicology. Sister chromatid test and chromosome aberrations are time consuming, resource intensive, require proliferating cell population [12], and not very effective due to the relatively large number of small chromosomes of many aquatic animal species. Theses disadvantages have stimulated the development and the use of comet assay and micronucleus test as simpler, more sensitive and time efficiency genotoxicity tests.

This review presents a synthesis of the state of the art in the methodologies of comet assay, and micronucleus test and their contributions in aquatic environmental research. The text explores the latest knowledge and thinking on these very important approaches for the assessment of environmental health, management, and conservation. The primary concern of the present review is the measurement of genotoxic potential in aquatic organisms under field and laboratory conditions, where effects of chemicals at different levels of biological organization can be examined.

\section{Comet Assay}

A more useful approach for assessing DNA damage is the single-cell gel (SCG) or comet assay. Comet Assay is one such state-of-the-art technique for quantitating DNA damage and repair in eukaryotic cells and some prokaryotic cells. The comet assay is a sensitive method to qualify and quantify DNA strand breaks occurring after compound induced genotoxicity and to detect the effect of environmental mutagen product in biomonitoring studies. Ostling and Johanson [13] were the first to develop a micro-cell gel electrophoresis technique for detecting DNA damage at the level of the single cell. Subsequently, Singh et al. [14] introduced a micro-cell gel technique involving electrophoresis under alkaline $(\mathrm{pH}>13)$ conditions for detecting DNA damage in single cells. The alkaline single cell gel electrophoresis is the most popular test to quantify DNA lesion in individual cells for environmental monitoring. The popularity of this test is due to its sensitivity, relatively low costs, simplicity and time efficiency due to automatic scoring of the comets by use of image-analysis software. Furthermore, the German Federal Environmental Agency proposes the comet assay as a useful test for a reliable detection of genotoxicity of surface waters. Alkaline comet assay is capable of detecting a wide variety of DNA damages such as DNA single-strand breaks, double-strand breaks, oxidatively induced base damages, alkali-labile 
sites, and sites undergoing DNA repair. It has been also employed to visualize DNA degradation due to apoptosis. If the damage produced is strong, it can finally lead to cell apoptosis. In this technique a cell suspension are embedded in low melting point agarose and placed on a microscope slide, lysed by detergents and high salt concentration at pH 10 to release nuclear DNA. The liberated DNA is electrophoresed under alkaline condition. Cells with increased DNA damage display increased migration of the DNA from the nucleus towards the anode under an electric field. The migrating DNA was quantified by staining with ethidium bromide and by measuring the intensity of fluorescence at two fixed positions within the migration pattern using a microscope photometer. Since the introduction of the alkaline $(\mathrm{pH}>13)$ comet assay in 1988, the breadth of application and the number of investigators using this technique have increased exponentially [15]. This assay is used in such diverse applications as genotoxicity testing, biomonitoring, and DNA damage induction and repair studies [16].

In the last 10 years many in-vivo and in-situ studies have been carried out on both aquatic invertebrates and fishes to investigate genotoxic effects on aquatic organisms. The comet assay has been widely used to investigate the impacts of environmental contaminants in the monitoring and biomonitoring program in fishes. A large number of studies reported that the comet assay is more sensitive when compared with other biomarkers commonly used in genetic ecotoxicology, such as sister chromatid exchanges or micronucleus test [17]. Osman et al. [2] monitored in detail the genotoxic potential of the river Nile by using comet assay. This study exhibited higher degree of DNA damage in blood of fish collected from downstream sites than that in blood of fish collected from upstream river Nile. Such damage was significantly elevated in peripheral blood erythrocytes of Nile tilapia and African catfish collected from heavily polluted areas. DNA damage in erythrocytes from Nile tilapia (Oreochromis niloticus niloticus) and African catfish (Clarias gariepinus) was shown to be related to contaminant levels in downstream areas. The simple progressive increase of genotoxicity levels along a water course found for the river Nile is a good example that DNA damages are associated, in the wild, with pollution levels when a gradient of pollution exists along the water course. Klobucar et al. [18] assessed the genotoxicity of freshwaters using caged carp (Cyprinus carpio). Carp from the sites with high anthropogenic influence had higher average DNA damage as expressed in comet assay. The results from this study suggest that 3 weeks caging exposure of C. carpio may be a useful strategy to monitor for genotoxic agents in freshwater ecosystems. The comet assay was used to detect genotoxicity due to multiple sources of pollution in the peripheral blood of a native fish species (Hyphessobrycon luetkenii) [19]. Water samples were collected seasonally from three sampling sites and the fish were assessed under laboratory conditions. The results of this study indicated that the Sinos River is contaminated with substances that are genotoxic to fish, including the waters near the river spring. Kopjar et al. [20] assessed of DNA integrity in erythrocytes using the alkaline comet assay to estimate the impacts of water pollution on Balkan loaches (Cobitis elongata) inhabiting the Sava and Kupa rivers. The results suggested a genotoxicity of the aquatic environment in the Sava River and demonstrated significantly lower levels of DNA damage in fish captured from the Kupa River. This study confirmed that the comet assay, applied to fish erythrocytes, is a useful tool in determining potential genotoxicity of water pollutants. Matsumoto et al. [21] subjected water samples from three sites in the Córrego dos Bagres stream in the Franca municipality of the Brazilian state of São Paulo to the comet assay using erythrocytes from the fish Oreochromis niloticus. The greatest comet assay damage occurred with water from a chromium-containing tannery effluent discharge site, supporting the hypothesis that chromium residues can be genotoxic. De Andrade et al. [22] used the alkaline comet assay to detect the genotoxicity due to multiple sources of pollution in the peripheral blood of two native estuarine fish (mullet and sea catfish) and evaluated possible interactive genotoxic effects from multiple contaminants and the seasonal variation of the genotoxicity. Fish captured in the two estuaries during the four seasons over a period of 2 years had increased levels of DNA damage relative to the reference fish. The increases in DNA damage appear to be related to the increase in the number of people in the towns close to the study areas. Whitehead et al. [23] tested whether agricultural chemical runoff was associated with instream genotoxicity in native fish. Using Sacramento sucker (Catostomus occidentalis), they combined field-caging experiments in an agriculturally dominated watershed with controlled laboratory exposures to field-collected water samples. They selected DNA strand breakage as a genotoxicity biomarker. Data from experiments indicated that DNA strand breaks were significantly elevated in fish exposed to San Joaquin River compared to a nearby reference site. Time-course measurements in field experiments supported a linkage between induction of DNA strand breakage and the timing of agricultural runoff. Rajaguru et al. [24] determined the genotoxic properties of water and sediment collected from the Noyyal River, which is polluted with industrial effluent and sewage, in fish (Cyprinus carpio) and earthworms (Eisenia foetida) using the alkaline comet assay. Upon electrophoresis, extensive DNA damage, measured as the 
DNA length: width ratio of the DNA mass, was observed in erythrocytes, liver, and kidney cells of fish exposed to polluted water samples and the amount of damage increased with the duration of exposure. Similarly, the mean DNA length: width ratio was significantly higher in the coelomocytes of earthworms placed in sediment samples. The highest levels of DNA damage were obtained with samples taken at downstream of urban centers. The results of this study indicate that the Noyyal River system is contaminated with substances that are genotoxic to fish and earthworms and that the comet assay has sufficient sensitivity to detect the genotoxicity. The sensitivity of the widely distributed freshwater bivalve mollusk Corbicula fluminea to the DNA-damaging alkylating-agent methylmethanesulfonate (MMS) were studies using comet assay [25]. The results of this work indicated that $C$. fluminea is an optimal bioindicator for the determination genotoxic contaminants in aquatic environments.

The comet assay has also proven to be a useful tool for investigating the genotoxic effects of in vitro and in vivo chemical exposure to aquatic invertebrate and fishes. Boettcher et al. [26] exposed rainbow-trout liver (RTL-W1) cells in vitro to acetone extracts of sediments collected at 10 selected sites along the upper Danube River and analyzed in the comet assay in order to correlate the genotoxic potential of sediments with genetic damage in fish. This in vitro bioassay showed excellent correlation, indicating comparability of genotoxic potentials in vitro. With respect to the ecological status of the Danube river, the results overall indicate a moderate to severe genotoxic potential with a highly differential localization. Fedato et al. [27] evaluated the genotoxic effects of acute exposures $(6,24$, and 96 h) to gasoline water soluble fraction (GWSF), diluted to 5\%, on the Asian clam Corbicula fluminea. The comet assay was performed on hemocytes and gill cells of $C$. fluminea. For the three different times tested, the comet assay indicated DNA damage in hemocytes and gill cells of $C$. fluminea exposed to GWSF. This result indicated that GWSF has genotoxic and mutagenic effects on C. fluminea. In addition, these results confirm the sensitivity of $C$. fluminea to damage caused by exposure to environmental contaminants, and, therefore, its suitability for use in environmental monitoring studies. Simoniello et al. [28] evaluated DNA damage using alkaline comet assay applied on erythrocytes after in vivo exposure of Prochiloduslineatus to different concentrations of Cypermethrin $(0.300,0.150,0.075$ and $0.000 \mathrm{lg} / \mathrm{L}$ ) as a probable chemical mutagen. The results revealed a significantly higher level of DNA damage at all concentrations of Cypermethrin tested compared to control and background level $(\mathrm{p}<0.05)$. They have standardized the technique for one of the most common native fish species that will be useful for biomonitoring genotoxicity in polluted waters of the region. The African catfish Clarias gariepinus were exposed to 100, 300, and $500 \mathrm{lg} / \mathrm{L}$ lead nitrate and DNA strand breakage was quantified in embryos at 30, 48, 96, 144, and $168 \mathrm{~h}$ post-fertilization (PFS) by using comet assay [29]. A strong correlation between lead concentration, time of exposure, and DNA strand breakage was observed. These results clearly show that the comet assay is a sensitive tool for the detection of genotoxicity in vulnerable early life stages of the African catfish. Ateeq et al. [30] evaluated the genotoxic potential of two widely used herbicides; 2,4-dichlorophenoxyacetic acid (2,4-D) and 2-chloro-2,6-diethyl-N-(butoxymethyl) acetanilide (butachlor) in erythrocytes of freshwater catfish, Clariasbatra chus. Fish were exposed by medium treatment with three sub-lethal concentrations of 2,4-D (25, 50, and $75 \mathrm{ppm})$ and butachlor $(1,2$, and $2.5 \mathrm{ppm})$ and alkaline comet assay was performed on nucleated erythrocytes after 48, 72, and $96 \mathrm{~h}$. A significant increase in comet tail length indicating DNA damage was observed at all concentrations of both the herbicides compared to the control. The mean comet tail length showed a concentration-related and time-dependent increase as the maximum tail length recorded at highest concentration and longer duration of 2,4-D (9.59 mm) and butachlor $(9.28 \mathrm{~mm})$. This study confirmed that the comet assay applied on the fish erythrocyte is a useful tool in determining potential genotoxicity of water pollutants and might be appropriate as a part of a monitoring program.

A possible genotoxic effect of surface water treated with disinfectants for potabilization was detected by Buschini et al. [31]. The comet assay was applied in circulating erythrocytes of Cyprinus carpio. Genotoxic damage was shown in fish exposed to water disinfected with sodium hypochlorite and chloride dioxide. The comet assay showed an immediate response, i.e. DNA damage that was induced directly in circulating erythrocytes, when genotoxic damage in stem cells of the cephalic kidney is expressed in circulating erythrocytes. The quality of the untreated surface water seems to be the most important parameter for the long-term DNA damage in circulating erythrocytes. Siu et al. [32] exposed Green-lipped mussels (Perna viridis) to water-borne benzo[a] pyrene $(\mathrm{B}[\mathrm{a}] \mathrm{P})$ at nominal concentrations of $0,0.3,3$ and 30 microg $1(-1)$ for up to 12 days, and the relative levels of DNA strand breaks were monitored in mussel haemocytes. The results of the comet assay indicated that an increase in the proportion of strand breaks occurred generally with increasing $\mathrm{B}[\mathrm{a}] \mathrm{P}$ concentration. They suggested that DNA strand breakage in mussel haemocytes can potentially be used as convenient biomarkers of 
exposure to genotoxicants in the marine environment. Coughlan et al. [33] measured genotoxic damage, expressed as single-strand DNA breaks, in cells isolated from haemolymph, gill and digestive gland from the clam Tapes semidecussatus, using the comet assay. Clams were exposed for three weeks to sediment samples collected from a polluted site and a clean reference site. Throughout the study, significant differences in DNA damage were recorded for each tissue type between clams exposed to the two sediment samples. They concluded that the comet assay is a useful tool for the detection of DNA damage in clams chronically exposed to polluted sediments. Schnurstein and Braunbeck [34] investigated the suitability of an in vitro version of the comet assay with primary hepatocytes and gill cells from zebrafish (Daniorerio). Within the scope of an 18month biomonitoring study, primary cells were used to identify the genotoxic potential of native water samples from different sites along the major German rivers, Rhine and Elbe, and to evaluate the sensitivity and practicability of the chosen assay. Depending on the endpoint measured, considerable differences were detected with respect to the number of genotoxic surface water samples.

\section{Micronuclei and Nuclear Lesions Tests}

Micronucleus test was proposed independently by Heddle [35] and Schmid [36] as an alternative and simpler approach to assess chromosome damage in vivo. The micronuclei $(\mathrm{MN})$ test is one of the most widely applied methods since it allows a convenient and easy application, in particular in genotoxicological studies with aquatic organisms. The micronuclei test has been used since the beginning of the 1980s to estimate the genotoxic effects of exposure to environmental contaminants. Micronuclei arise from chromosome fragments or whole chromosomes that lag at cell division due to lack of centromere, damage in centromere region, or defect in cytokinesis. These fragments left behind are incorporated in the secondary nuclei, called micronuclei (MN). Micronuclei formation can occur in any of the dividing cells of any species. The count of micronuclei has served as an index of chromosome breaks and mitotic spindle apparatus dysfunction [37]. In environmental mutagenesis investigations, the MN test using aquatic organisms has proved to be a simple, reliable, sensitive, and inexpensive procedure to assess the biological impact of water pollution. It has been assessed in aquatic organism as a biological indicator of pollution in wild areas, and also for genotoxicity evaluation of physical and chemical agents after direct or indirect exposure in vivo [15]. The MN test presents several advantages over other cytogenetic studies such as sister chromatid exchanges or chromosome aberrations, which are time-consuming and not very effective due to the relatively large number of small chromosomes of many aquatic animal species. Nuclear lesions (NL) are genotoxic analogues of MN that may also be the result of the action of a genotoxic agent. These lesions have been considered to be of genotoxic origin by some authors and used by others as a signal of cytogenetic damage in aquatic species. Most of the nuclear lesions have a similar origin as MN and are established to be a genotoxic indicator. Such abnormal cell division would result in genetic imbalance of the cells, which may also be involved in carcinogenesis [38]. Some authors suggested that some nuclear lesions could be a precursor of $\mathrm{MN}$, and represent a process for eliminating amplified genes from the nucleus. Since teleost erythrocytes are nucleated, micronuclei and nuclear lesions tests have been scored in fish erythrocytes as a measure of clastogenic activity. According to my experiences the peripheral erythrocytes of fish have a high incidence of MN after exposure to different pollutants under field and laboratory conditions. High mitotic rate of hematopoietic tissues provide a rapid response to genotoxic exposure revealed as chromosomal damage in peripheral blood [39].

The micronucleus (MN) test, one of those most frequently used in environmental genotoxicity studies, has served as an index of cytogenetic damage for over 30 years [40]. The micronucleus test is a simple and sensitive assay for "in situ, in vivo and in vitro" evaluation of genotoxic properties in aquatic environment as a part of the biomonitoring programs. Obiakor et al. [41] explored the biomonitoring potentials of micronucleus test on waterborne pollutants. It then considers the interplay between such micronucleus formations and certain widespread environmental pollutants. In their biomonitoring studies Osman et al. [1] detected six nuclear lesions NL beside micronuclei (MN) in the blood of Nile tilapia Oreochromis niloticus niloticus and African catfish Clarias gariepinus collected from the whole course of the rive Nile. According to this result higher incidences of MN and NL were found in the blood of fish collected from the heavily polluted areas. The simple progressive increase of MN and NL frequencies along a water course found for the River Nile is a good example that MN counts are associated, in the wild, with pollution levels expected when a gradient of pollution exists along the water course [1]. The results of this study confirm the usefulness of the erythrocyte MN and NL as powerful monitoring tools for detecting genotoxic agents in fresh water environment. This conclusion was previously 
supported by Rybakovas et al. [3] who analyzed Micronuclei (MN), nuclear buds (NB) and fragmented-apoptotic cells (FA) in mature peripheral blood and immature cephalic kidney erythrocytes of flounder (Platichthys flesus), dab (Limanda limanda) and cod (Gadus morhua) from 12 offshore sites in the Baltic Sea and 11 sites in the North. The highest levels of environmental genotoxicity were observed in flatfishes from areas close to oil and gas platforms in the North Sea and in zones related to the extensive shipping and potentially influenced by contamination from large European Rivers (Elbe, Vistula, Oder). In dab from the offshore zones of the North Sea, the levels of nuclear abnormalities were higher as compared to those in dab from the Baltic Sea. In the same context Pavlica et al. [42] determined the frequency of micronuclei (MN) in haemocytes of native mussels, Mytilus galloprovincialis, collected at five sites along the Eastern Adriatic coast in Croatia, four times throughout the year to evaluate seasonal variability in connection with possible genotoxic pollution. Chosen sites were either near closed industrial facilities or in tourist resorts. Mussels from a mussel farm were used as control. The highest frequency of MN was observed in summer on all studied sites, elevated in comparison to the control. These results pointed out that seasonal changes were observed only at polluted sites, most probably caused by seasonality of pollution as well as by interaction between contaminants and higher metabolic and filtration rates in mussels, resulting in higher values of cytogenetic damage. Baršienè et al. [43] analyzed the frequency of micronuclei (MN) in gill cells of 97 specimens of blue mussels (Mytilus edulis), in peripheral blood of 61 specimens of flounder (Platychthys flesus) and 40 specimens of wrasse (Symphodus melops), which were collected from seven study locations in the Göteborg area of the North Sea. Ten times higher frequencies of micronuclei were found in flounder collected from the contaminated zone at Jordhammarvik and eight times higher micronuclei levels were recorded in fish from Nya Alvsborg, the inner part of the Göteborgharbour. In mussels, the highest response was established in specimens inhabiting the Ringhals zone. The use of Brown trout, Salmotrutta, European eel, Anguilla anguilla, and European minnow, Phoxinus phoxinus, as in situ pollution bioindicators were evaluated by Rodriguez-Cea et al. [44] using the micronucleus test in renal erythrocytes. In situ surveys of wild freshwater ecosystems with different levels of pollution showed that micronuclei are induced in brown trout inhabiting polluted sites. This result demonstrated the suitability of brown trout for in situ biomonitoring of freshwater ecosystems.

The micronucleus test is considered to be one of the most efficient approaches for the assessment of exposure to contaminants [40]. Baršienè et al. [45] studied the genotoxicity of crude oil processed from the Statfjord B platform in the North Sea in gills of blue mussels (Mytilus edulis), exposed to $0.5 \mathrm{ppm}$ concentration of the dispersed oil for 1, 2, 4 and 8 days. Time-related MN elevation incidences were detected in all experimental groups compared to the control group of mussels. The elevation of micronuclei increased progressively with increasing the duration of exposure. Barsiene et al. [46] assessed the genotoxicity, cytotoxicity and immunotoxicity potential of treated wastewater effluents (TWE) discharged from the Vilnius Wastewater Treatment Plant. The analysis of micronuclei, nuclear buds (genotoxicity endpoints), bi-nucleated and fragmented apoptotic cells (cytotoxicity endpoints) in peripheral blood of rainbow trout (Oncorhynchus mykiss) after a 12-day exposure to TWE revealed a significant increase of micronuclei in exposed $O$. mykiss specimens compared to control fish. Çavas and Ergene-Gözükara [47] evaluated the genotoxic effects of effluents from a petroleum refinery and a chromium processing plant in Oreochromis niloticus using the micronucleus test. Fish were exposed to different concentrations (5\%,10\% and 20\%, v/v) of the effluents for 3, 6 and 9 days. The results of this study showed that both effluents had genotoxic potential. On the other hand, the level of genetic damage induced by petroleum refinery effluent was considerably higher than that of chromium processing plant effluent. This result further indicates that nuclear abnormalities other than micronuclei may also be used as indicators of genotoxic damage.

\section{Acknowledgements}

This work was conducted during 2013-2014 in the framework of an Alexander von Humboldt foundation return fellowship for the author, hosted by Faculty of Science, Al-Azhar University, Assiut, Egypt.

\section{References}

[1] Osman, A.G., Abd El Reheema, A.M., Moustafa, M.A., Mahmoud, U.M., Abuel-Fadld, K.Y. and Kloas, W. (2011) In Situ Evaluation of the Genotoxic Potential of the River Nile: I. Micronucleus and Nuclear Lesion Tests of Erythrocytes of Oreochromis niloticus niloticus (Linnaeus, 1758) and Clarias gariepinus (Burchell, 1822). Toxicological and Environmental Chemistry, 93, 1002-1017. http://dx.doi.org/10.1080/02772248.2011.564496 
[2] Osman, A.G., Abuel-Fadl, K.Y. and Kloas, W. (2012) In Situ Evaluation of the Genotoxic Potential of the River Nile: II. Detection of DNA Strand-Breakage and Apoptosis in Oreochromis niloticus niloticus (Linnaeus, 1758) and Clarias gariepinus (Burchell, 1822). Mutation Research, 747, 14-21. http://dx.doi.org/10.1016/j.mrgentox.2012.02.013

[3] Rybakovas, A., Barsiene, J. and Lang, T. (2009) Environmental Genotoxicity and Cytotoxicity in Offshore Zones of the Baltic and North Seas. Marine Environmental Research, 68, 246-256. http://dx.doi.org/10.1016/j.marenvres.2009.06.014

[4] Lam, P.K.S. and Gray, J.S. (2003) The Use of Biomarkers in Environmental Monitoring Programmes. Marine Pollution Bulletin, 46, 182-186.

[5] Würgler, F.E. and Kramers, P.G. (1992) Environmental Effects of Genotoxins (Eco-Genotoxicology). Mutagenesis, 7, 321-327. http://dx.doi.org/10.1093/mutage/7.5.321

[6] Anderson, S.L. and Wild, G.C. (1994) Linking Genotoxic Responses to Reproductive Success in Ecotoxicology. Environmental Health Perspectives, 102, 9-12. http://dx.doi.org/10.1289/ehp.94102s129

[7] Jha, A.N., Cheung, V.V., Foulkes, M.E., Hill, S.J. and Depledge, M.H. (2000) Detection of Genotoxins in the Marine Environment: Adoption and Evaluation of an Integrated Approach Using the Embryo-Larval Stages of the Marine Mussel, Mytilusedulis. Mutation Research, 464, 213-228. http://dx.doi.org/10.1016/S1383-5718(99)00188-6

[8] De Flora, S., Bagnasco, S. and Zanacchi, M. (1991) Genotoxic, Carcinogenic and Teratogenic Hazards in the Marine Environment, with Special Reference to the Mediterranean Sea. Mutation Research, 258, 285-320. http://dx.doi.org/10.1016/0165-1110(91)90013-L

[9] Lee, R. and Steinert, S. (2003) Use of the Single Cell Gel Electrophoresis/Comet Assay for Detecting DNA Damage in Aquatic (Marine and Freshwater) Animals. Mutation Research/Reviews in Mutation Research, 544, 43-64. http://dx.doi.org/10.1016/S1383-5742(03)00017-6

[10] McCarthy, J.F. and Shugart, L.R. (1990) Biological Markers of Environmental Contamination. In: McCarthy, J.F. and Shugart, L.R., Eds., Biomarkers of Environmental Contamination, Lewis Publishers, Boca Raton, 3-14.

[11] Shugart, L.R. (1999) Structural Damage to DNA in Response to Toxicant Exposure. In: Forbes, V.E., Ed., Genetics and Ecotoxicology, Taylor \& Francis, London, 151-167.

[12] Muid, K.A., Shahjahan, R.M., Begum, R. and Begum, R.A. (2012) Zinc Phosphide Induced DNA Damage in the Blood Cells of Gallus sp. Using Comet DNA Assay. American Journal of Agricultural and Biological Sciences, 7, 8287. http://dx.doi.org/10.3844/ajabssp.2012.82.87

[13] Ostling, O. and Johanson, K.J. (1984) Microelectrophoretic Study of Radiation-Induced DNA Damages in Individual Mammalian Cells. Biochemical and Biophysical Research Communications, 123, 291-298. http://dx.doi.org/10.1016/0006-291X(84)90411-X

[14] Singh, N., McCoy, M., Tice, R. and Schneider, E. (1988) A Simple Technique for Quantitation of Low Levels of DNA Damage in Individual Cells. Experimental Cell Research, 175, 184-191. http://dx.doi.org/10.1016/0014-4827(88)90265-0

[15] Osman, A.G. and Kloas, W. (2012) Biomarker Responses in Fishes: A Tool for Monitoring Water Quality of the River Nile. Cuvillier Verlag, Göttingen.

[16] Jarvis, R.B. and Knowles, J.F. (2003) DNA Damage in Zebrafish Larvae induced by Exposure to Low-Dose Rate Gamma-Radiation: Detection by the Alkaline Comet Assay. Mutation Research-Genetic Toxicology and Environmental Mutagenesis, 541, 63-69. http://dx.doi.org/10.1016/S1383-5718(03)00182-7

[17] Frenzilli, G., Nigro, M. and Lyons, B.P. (2009) The Comet Assay for the Evaluation of Genotoxic Impact in Aquatic Environments. Mutation Research, 681, 80-92. http://dx.doi.org/10.1016/j.mrrev.2008.03.001

[18] Klobucar, G.I., Stambuk, A., Pavlica, M., Sertic Peric, M., Kutuzovic Hackenberger, B. and Hylland, K. (2010) Genotoxicity Monitoring of Freshwater Environments Using Caged Carp (Cyprinus carpio). Ecotoxicology, 19, 77-84. http://dx.doi.org/10.1007/s10646-009-0390-6

[19] Scalon, M.C.S., Rechenmacher, C.B., Siebel, A.M., Kayser, M.L., Rodrigues, M.T., Maluf, S.W., Ro-drigues, M.A.S., and Silva, L.B. (2010) Evaluation of Sinos River Water Genotoxicity Using the Comet Assay in Fish. Brazilian Journal of Biology, 70, 1217-1222. http://dx.doi.org/10.1590/S1519-69842010000600011

[20] Kopjar, N., Mustafić, P., Zanella, D., Buj, I., Ćaleta, M., Marčić, Z., Milić, M., Dolenec, Z. and Mrakovčić, M. (2008) Assessment of DNA Integrity in Erythrocytes of Cobitis elongata Affected by Water Pollution: The Alkaline Comet Assay Study. Folia Zoologica, 57, 120-130.

[21] Matsumoto, S.T., Mantovani, M.S., Malaguttii, M.I., Dias, A.L., Fonseca, I.C. and Marin-Morales, M.A. (2006) Genotoxicity and Mutagenicity of Water Contaminated with Tannery Effluents, as Evaluated by the Micronucleus Test and Comet Assay Using the Fish Oreochromis niloticus and Chromosome Aberrations in Onion Root Tips. Genetic and Molecular Biology, 29, 148-158. http://dx.doi.org/10.1590/S1415-47572006000100028

[22] De Andrade, V.M., De Freitas, T.R.O. and Da Silva, J. (2004) Comet Assay Using Mullet (Mugil sp.) and Sea Catfish 
(Netuma sp.) Erythrocytes for the Detection of Genotoxic Pollutants in Aquatic Environment. Mutation Research, 560, 57-67. http://dx.doi.org/10.1016/j.mrgentox.2004.02.006

[23] Whitehead, A., Kuivila, K.M., Orlando, J.L., Kotelevtsev, S. and Anderson, S.L. (2004) Genotoxicity in Native Fish Associated with Agricultural Runoff Events. Environmental Toxicology and Chemistry, 13, 2868-2877. http://dx.doi.org/10.1897/03-649.1

[24] Rajaguru, P., Suba, S., Palanivel, M. and Kalaiselvi, K. (2003) Genotoxicity of a Polluted River System Measured Using the Alkaline Comet Assay on Fish and Earthworm Tissues. Environmental and Molecular Mutagenesis, 91, 85-91. http://dx.doi.org/10.1002/em.10134

[25] Rigonato, J., Mantovani, M.S. and Jordão, B.Q. (2005) Comet Assay Comparison of Different Corbicula fluminea (Mollusca) Tissues for the Detection of Genotoxicity. Genetic and Molecular Biology, 28, 464-468. http://dx.doi.org/10.1590/S1415-47572005000300023

[26] Boettcher, M., Grund, S., Keiter, S., Kosmehl, T., Reifferscheid, G., Seitz, N., Rocha, P.S., Hollert, H. and Braunbeck, T. (2010) Comparison of in Vitro and in Situ Genotoxicity in the Danube River by Means of the Comet Assay and the Micronucleus Test. Mutation Research, 700, 11-17. http://dx.doi.org/10.1016/j.mrgentox.2010.04.016

[27] Fedato, R.P., Simonato, J.D., Martinez, C.B.R. and Sofiaa, S.H. (2010) Genetic Damage in the Bivalve Mollusk Corbicula fluminea Induced by the Water-Soluble Fraction of Gasoline. Mutation Research, 700, 80-85. http://dx.doi.org/10.1016/j.mrgentox.2010.05.012

[28] Simoniello, M.F., Gigena, F., Poletta, G., Loteste, A., Kleinsorge, E., Campana, M., Scagnetti, J. and Parma, M.J. (2009) Alkaline Comet Assay for Genotoxic Effect Detection in Neotropical Fish Prochilodus lineatus (Pisces, Curimatidae). Bulletin of Environmental Contamination and Toxicology, 83, 155-158. http://dx.doi.org/10.1007/s00128-009-9771-z

[29] Osman, A.G., Mekkawy, I.A.A., Verreth, J., Wuertz, S., Kloas, W. and Kirschbaum, F. (2008) Monitoring of DNA Breakage in Embryonic Stages of the African Catfish Clarias gariepinus (Burchell, 1822) after Exposure to Lead Nitrate Using Alkaline Comet Assay. Environmental Toxicology, 23, 679-687. http://dx.doi.org/10.1002/tox.20373

[30] Ateeq, B., Farah, M.A. and Ahmad, W. (2005) Detection of DNA Damage by Alkaline Single Cell Gel Electrophoresis in 2,4-Dichlorophenoxyacetic-Acid- and Butachlor-Exposed Erythrocytes of Clarias batrachus. Ecotoxicology and Environmental Safety, 62, 348-354. http://dx.doi.org/10.1016/j.ecoenv.2004.12.011

[31] Buschini, A., Martino, A., Gustavino, B., Monfrinotti, M., Poli, P., Rossi, C., Santoro, M., Dörr, A. and Rizzoni, M. (2004) Comet Assay and Micronucleus Test in Circulating Erythrocytes of Cyprinus carpio Specimens Exposed in Situ to Lake Waters Treated with Disinfectants for Potabilization. Mutation Research, 557, 19-129. http://dx.doi.org/10.1016/j.mrgentox.2003.10.008

[32] Siu, W.H.L., Cao, J., Jack, R.W., Wu, R.S.S., Richardson, B.J., Xu, L. and Lam, P.K.S. (2004) Application of Comet and Micronucleus Assays to the Detection of $\mathrm{B}(a) \mathrm{P}$ Genotoxicity in Haemocytes of the Green-Lipped Mussel (Perna viridis). Aquatic Toxicology, 66, 381-392. http://dx.doi.org/10.1016/j.aquatox.2003.10.006

[33] Coughlan, B.M., Hartl, M.G.J., O’Reilly, S.J., Sheehan, D., Morthersill, C., van Pelt, F., O’Halloran, J. and O’Brien, N.M. (2002) Detecting Genotoxicity Using the Comet Assay Following Chronic Exposure of Manila Clam Tapes semidecussatus to Polluted Estuarine Sediments. Marine Pollution Bulletin, 44, 1359-1365. http://dx.doi.org/10.1016/S0025-326X(02)00254-0

[34] Schnurstein, A. and Braunbeck, T. (2001) Tail Moment versus Tail Length-Application of an in Vitro Version of the Comet Assay in Biomonitoring for Genotoxicity in Native Surface Waters Using Primary Hepatocytes and Gill Cells from Zebrafish (Danio rerio). Ecotoxicology and Environmental Safety, 49, 187-196.

http://dx.doi.org/10.1006/eesa.2001.2050

[35] Heddle, J.A. (1973) A Rapid in Vivo Test for Chromosomal Damage. Mutation Research, 18, 187-190. http://dx.doi.org/10.1016/0027-5107(73)90035-3

[36] Schmid, W. (1975) The Micronucleus Test. Mutation Research, 31, 9-15. http://dx.doi.org/10.1016/0165-1161(75)90058-8

[37] Ayllon, F. and Garcia-Vazquez, E. (2000) Induction of Micronuclei and Other Nuclear Abnormalities in European Minnow Phoxinus phoxinus and Mollie Poecilia latipinna: An Assessment of the Fish Micronucleus Test. Mutation Research, 467, 177-186. http://dx.doi.org/10.1016/S1383-5718(00)00033-4

[38] Rodilla, V. (1993) Origin and Evolution of Binucleated Cells and Binucleated Cells with Micronuclei in CisplatinTreated CHO Cultures. Mutation Research, 300, 281-291. http://dx.doi.org/10.1016/0165-1218(93)90062-I

[39] Bolognesi, C., Perrone, E., Roggieri, P., Pampanin, D.M. and Sciutto, A. (2006) Assessment of Micronuclei Induction in Peripheral Erythrocytes of Fish Exposed to Xenobiotics under Controlled Conditions. Aquatic Toxicology, 78, S93S98. http://dx.doi.org/10.1016/j.aquatox.2006.02.015

[40] Fenech, M., Chang, W.P., Kirsch-Volders, M., Holland, N., Bonassi, S. and Zeiger, E. (2003) HUMN Project: Detailed 
Description of the Scoring Criteria for the Cytokinesis-Block Micronucleus Assay Using Isolated Human Lymphocyte Cultures. Mutation Research, 534, 65-75. http://dx.doi.org/10.1016/S1383-5718(02)00249-8

[41] Obiakor, M.O., Okonkwo, J.C., Nnabude, P.C. and Ezeonyejiaku, C.D. (2012) Eco-Genotoxicology: Micronucleus Assay in Fish Erythrocytes as in Situ Aquatic Pollution Biomarker: A Review. Journal of Animal Science Advances, 2, 123-133.

[42] Pavlica, M., Podrug, M., Štambuk, A., Cvjetko, P. and Klobučar, G.I.V. (2008) Seasonal Variability in Micronuclei Induction in Haemocytes of Mussels along the Eastern Adriatic Coast. Polish Journal of Environmental Studies, 17, 765-771.

[43] Baršienė, J., Lehtonen, K., Koehler, A., Broeg, K., Vourinen, P.J., Lang, T., Pempkowiak, J., Šyvokienė, J., Dedonytė, V., Rybakovas, A., Repečka, R., Vountisjarvi, H. and Kopecka, J. (2006) Biomarker Responses in Flounder (Platichthys flesus) and Mussel (Mytilus edulis) in the Klaipèda-Būtingè Area (Baltic Sea). Marine Pollution Bulletin, 53, $422-$ 436. http://dx.doi.org/10.1016/j.marpolbul.2006.03.009

[44] Rodriguez-Cea, A., Ayllon, F. and Garcia-Vazquez, E. (2003) Micronucleus Test in Freshwater Fish Species: An Evaluation of Its Sensitivity for Application in Field Surveys. Ecotoxicology and Environmental Safety, 56, 442-448. http://dx.doi.org/10.1016/S0147-6513(03)00073-3

[45] Baršienè, J., Andreikènaitè, L. and Bjornstad, A. (2010) Induction of Micronuclei and Other Nuclear Abnormalities in Blue Mussels Mytilusedulis after 1-, 2-, 4- and 8-Day Treatment with Crude Oil from the North Sea. Ekologija, 56, 124-131. http://dx.doi.org/10.2478/v10055-010-0018-4

[46] Barsiene, J., Andreikenaite, L., Vosyliene, M.Z. and Milukaite, A. (2009) Genotoxicity and Immunotoxicity of Wastewater Effluents Discharged from Vilnius Wastewater Treatment Plant. Acta Zoologica Lituanica, 19, 188-196. http://dx.doi.org/10.2478/v10043-009-0025-4

[47] Çavas, T. and Ergene-Gözükara, S. (2005) Induction of Micronuclei and Nuclear Abnormalities in Oreochromis niloticos Following Exposure to Petroleum Refinery and Chromium Processing Plant Effluents. Aquatic Toxicology, 74, 264-271. http://dx.doi.org/10.1016/j.aquatox.2005.06.001 
Scientific Research Publishing (SCIRP) is one of the largest Open Access journal publishers. It is currently publishing more than 200 open access, online, peer-reviewed journals covering a wide range of academic disciplines. SCIRP serves the worldwide academic communities and contributes to the progress and application of science with its publication.

Other selected journals from SCIRP are listed as below. Submit your manuscript to us via either submit@scirp.org or Online Submission Portal.
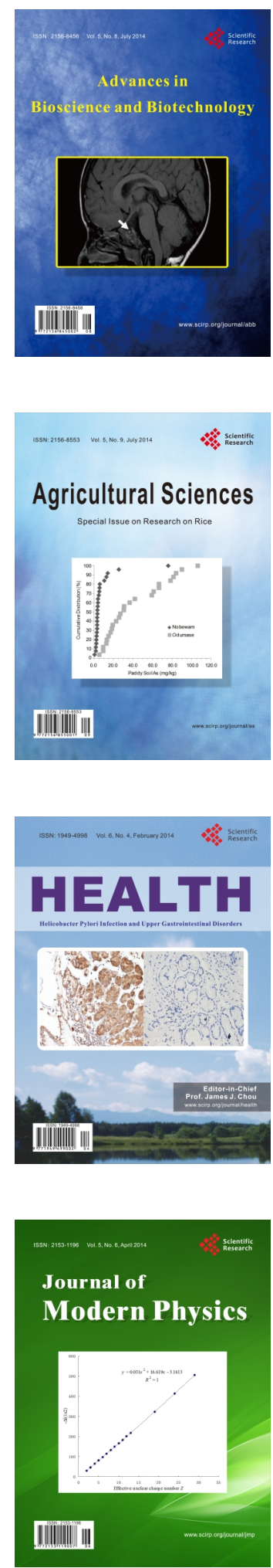
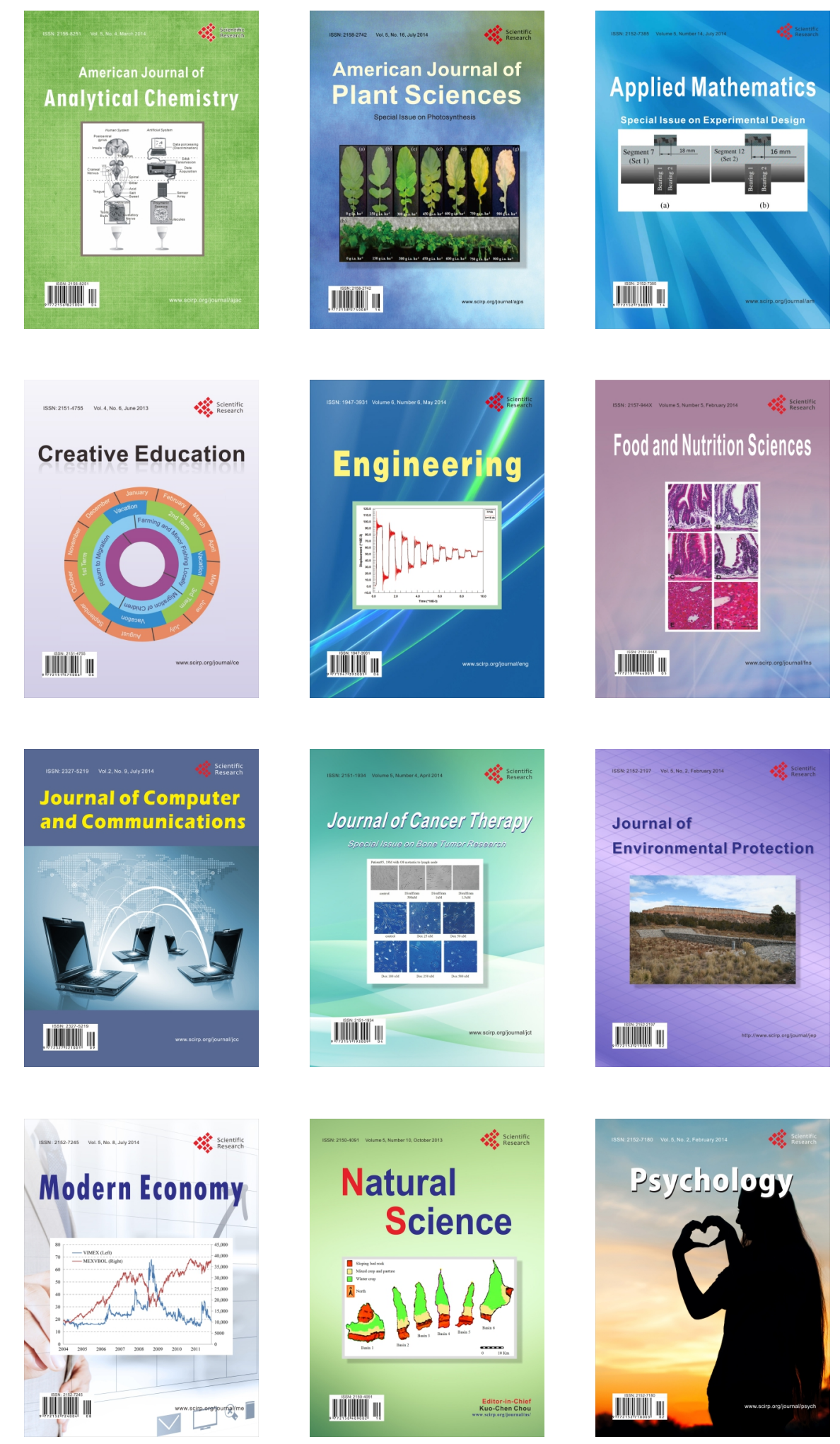